\title{
Combination of Tilt-Angle and Euler Deconvolution Approaches to Determine Structural Features from Aeromagnetic Data Modeling over Akonolinga-Loum Area (Centre-East, Cameroon)
}

\author{
Justine Yandjimain1, Théophile Ndougsa-Mbarga1,2*, Arsène Meying3, Marcelin Bikoro Bi-Alou4, \\ Paul Claude Ngoumou'2, Stéphane Patrick Assembe5, Jean Daniel Ngoh'1, \\ Olivier Ulrich Igor Owono-Amougou 1
}

\author{
${ }^{1}$ Postgraduate School of Sciences, Technologies \& Geosciences, University of Yaoundé I, Yaoundé, Cameroon \\ ${ }^{2}$ Department of Physics, Advanced Teacher's Training College, University of Yaoundé I, Yaoundé, Cameroon \\ ${ }^{3}$ Department of Applied Geophysics, Geology and Mining Exploitation College, University of Ngaoundéré, Ngaoundéré, \\ Cameroun \\ ${ }^{4}$ Department of Earth Sciences, Faculty of Science, University of Maroua, Maroua, Cameroon \\ ${ }^{5}$ Department of Physics, Faculty of Science, University of Bamenda, Bambili, Cameroon \\ Email: *tndougsa@yahoo.fr
}

How to cite this paper: Yandjimain, J., Ndougsa-Mbarga, T., Meying, A., Bi-Alou, M.B., Ngoumou, P.C., Assembe, S.P., Ngoh, J.D. and Owono-Amougou, O.U.I. (2017) Combination of Tilt-Angle and Euler Deconvolution Approaches to Determine Structural Features from Aeromagnetic Data Modeling over Akonolinga-Loum Area (CentreEast, Cameroon). International Journal of Geosciences, 8, 925-947.

https://doi.org/10.4236/ijg.2017.87053

Received: June 5, 2017

Accepted: July 25, 2017

Published: July 28, 2017

Copyright $\odot 2017$ by authors and Scientific Research Publishing Inc. This work is licensed under the Creative Commons Attribution International License (CC BY 4.0).

http://creativecommons.org/licenses/by/4.0/

\section{Abstract}

Aeromagnetic data for center-east Cameroon between the latitudes $3.5^{\circ}$ to $4.5^{\circ} \mathrm{N}$ and longitudes $12^{\circ}$ to $12.5^{\circ} \mathrm{E}$ are used to further study the subsurface area of this part of the geological Province of Central Africa and the Congo Craton. The GIS and GEOSOFT v6.5 softwares are used to treat the data. This analysis enabled us to explore our study area from surface right to the base. The Tilt Angle method is used to delineate geological structures and to estimate the depth. The Euler's deconvolution method is used to estimate the specific depth of structural contacts. We estimate the northern boundary of the Congo Craton and southern boundary of the Pan-African starting from $3^{\circ} 7^{\prime} \mathrm{N}$ of West to $3^{\circ} 75^{\prime} \mathrm{N}$ of East. Its depth is estimated around $2.6 \mathrm{~km}$ for deep and $0.1 \mathrm{~km}$ for shallow while the direction is WSW-ENE and the NW slope varies from $30^{\circ}$ to $60^{\circ}$. We obtain that main and minor lineaments exist throughout, from the surface to the base of the area with their principal direction being SW-NE. We also obtain the vertical gradient contact and the quasihorizontal contact. This is proof of the subduction of the Pan-African belt under the Congo Craton due to the intense collision which caused the rejuvenation of the crust. The main consequence of this collision is the formation of pudding 
and fold structures, beginning from the superficial part right to the base and which caused the intrusion of schistose, chlorite-schist, quartzite in the micaschist and the intrusions of gneiss and garnetiferous schist in the migmatite. In our study, we highlight the presence of 37 major and 523 minor lineaments that localize the circulation of minerals. The probable slope of the lineaments in the northern part of the region varies from $30^{\circ}$ to $60^{\circ}$ in a SE direction while in the southern part, and it varies from $30^{\circ}$ to $60^{\circ}$ in a NW direction.

\section{Keywords}

Tilt-Angle, Euler Deconvolution, Lineaments, Fault, Gradient, Akonolinga-Loum

\section{Introduction}

The Magnetic method is one of the best geophysical techniques used to delineate subsurface structures. Generally, aeromagnetic maps reflect the variations in Earth's magnetic field. The study area is located in the Center-East region of Cameroon (Central Africa). It is situated in northern hemisphere, between the meridians $12^{\circ} 00^{\prime}$ and $12^{\circ} 30^{\prime}$ of longitudes East and parallels $3^{\circ} 30^{\prime}$ and $4^{\circ} 30^{\prime}$ of latitudes North, with an average altitude of $700 \mathrm{~m}$. More recently, combined studies of geochemistry and geology in this area were affected by a series of tectonic events due to the collision between the Pan-African belt and the Congo Craton that formed the structural features of south Cameroon [1] [2] [3] [4] [5]. The collision yielded to an over thrusting of the Pan-African units onto the Craton of about 50 to $150 \mathrm{~km} \mathrm{[6]} \mathrm{[7]} \mathrm{[8]} \mathrm{[9].} \mathrm{Other} \mathrm{studies} \mathrm{combining} \mathrm{geology} \mathrm{and} \mathrm{geo-}$ physics were conducted in this area to estimate the mineral resources [10] [11] and to estimate the probable position of the Congo Craton boundary [7] [10] [12]. All of these studies showed the main lineaments in this region. The base faults are very difficult to highlight [13]. The same authors underline the difficulty of interpreting the directions of folds in the base. To the South of our study area, [14] have underlined the major network lineaments identified in the area under study which extend from the SW to NE with a major trend WSW-ENE and can also be connected to those identified SW-NE by [6]. Do these major network lineaments extend to our region of study? The use of aeromagnetic data enabled us to study the major and minor structures in their depth and geometries and thus to highlight the presence of mineral resources.

\section{Geology and Tectonic Setting}

The geological mapping of the study area (Figure 1) was first done by [13] [15]. The study area encompasses a $6207.73 \mathrm{~km}^{2}$ area that includes rocks resulting from the intermediate series, made up of schist and quartzite formed following an epizonal metamorphism. This is composed of series rocks of magnesians and migmatite. The area is included also in the Yaounde series and it is constituted 


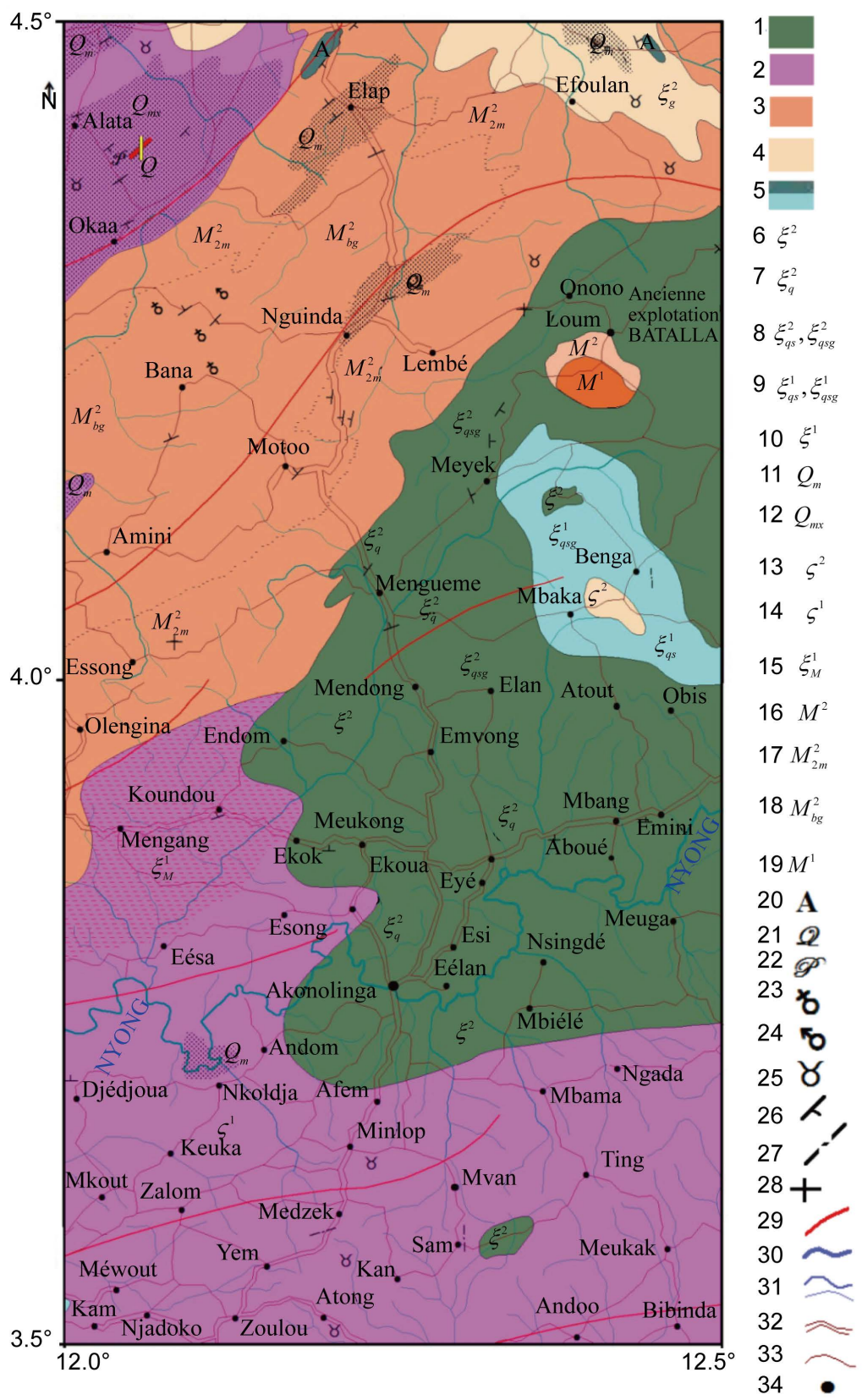

Figure 1. Geologic map of the study area (copy [13]), modified. LEGEND: 1 Schists, 2 Mica-schists, 3 Compound gneisses, 4 Gneisses, 5 quartzose schisto- Group; schistoquartzose Group: 6 Schist, quartzites, 7 Quartzites dominant, 8 Schists, chlorite-schists, quarzites (and Schists, chlorite-schists, quartzites and grenatiferous), 9 Mica schists with two micas and quartzites (and Mica-schists with two micas and quartzites and grenatiferous); Complex basic: 10 Mica schists with two micas (and/or Gneiss grenatiferous with two micas), 11 Quarzites micaceous, 12 Quartzites minerals; Gneiss: 13 Gneiss with two micas (and/or Gneiss grenatiferous with two micas), 14 Biotite Gneiss; 15 Migmatized Mica schists grenatiferous, 16 Gneiss embrechists grenatiferous, 17 Embrechists with two micas, 18 Compound gneisses of Ayna, 19 Anatexites; 20 Paraamphibolites; Seams: 21 Seams Quartz, 22 Seams pegmatite, Conventional signs: 23 Manganiferous Minerals, 24 Monazite, 25 Titanium Ore, 26 slops and direction, 27 Vertical slops, 28 Horizontal Layers, 29 Tectonic Lines; Topography: 30 Nyong, 31 rivers, 32 Roads, 33 Tracks, 34 Towns. 
of garnetiferous gneiss and migmatite embrechites, and of garnetiferous migmatites and micaschists [13]. It belongs indeed to the meta-sediments series of Dja-Ayos-Mbalmayo-Bengbis, [16]. Pelitic schists have been identified along the Yaounde-Akonolinga axis [17]. [18] considered the Ayos, the Mbalmayo and the Bengbis basins as being of a Precambrian mean age. Structurally, the Yaounde series are made up of juxtaposed rock units which are interpreted as a large nap that is thrusted southward onto the Congo Craton [19]. The series of AyosMbalmayo-Bengbis-Akonolinga are mainly composed of schist and quartzite. The composition is made up of chlorite-schist, mica-schist with or without muscovite, gneiss and slate with numerous veins of quartzite running through them. The series of Ayna is mainly composed of ectinites and migmatite. The composition is made up of gneiss, quartzite and mineral quartzites. The base complex series of garnet is mainly composed of ectinites and migmatites. As for ectinite, it constituted of mica-schist, gneiss and mica-quartzite while migmatite is constituted of mica-schist migmatite and embreschite gneiss. The quartz and pegmatite vein are observed in the north-western part of the region [13] [15]. The study area is a part of the mobile area between the Congo Craton (CC) (southern portion of area) and the Pan-African (northern portion of area). Its formation dates back to the rejuvenation during the Pan-African orogeny about $550 \mathrm{Ma}$ ago [19] [20] [21]. It is largely intruded by Neoproterozoic granitic of Pan-African age emplaced from the early stages of deformation up to the late uplift stage of the evolution of the Central African Fold Belt (CAFB). The deep fold and fault system is oriented E-W, and those showing uplifting and a fault zone juxtaposed the high-density Pan-African domain in the north against the low-density Archean rocks in the south, with variable crustal depth from $8 \mathrm{~km}$ to $20 \mathrm{~km}$ [7] [22]. The mica-schist of this region is thought to have been formed on top of the chlorite-schist. The primary minerals of the schist include muscovite, biotite, quartz and garnet, disthene, rutile and ilmenite as its secondary minerals [11] [16]. The schist and mica-schist are relatively less faulted.

The study area presents the majors tectonic features that result from the extension of the Congo Craton under the Pan-African units. This event marks the subduction of the Congo Craton under the Pan-African belt. This subduction is responsible for the deep fractures in covers. The tectonic lines have directed SW-NE (Figure 1). Geophysical studies [7] [10] [23] show that the boundary of $\mathrm{CC}$ and Pan-African is around $4^{\circ} \mathrm{N}$. The tectonic features (faults and folds) are fitted into the CAFB's deformation history and could be due to the Tran Saharan east-west collision system [24]. Some buried faults have being confirmed in the geophysical studies [11] [23] [25].

\section{Aeromagnetic Data and Methods}

\subsection{Origin of Data}

The aeromagnetic data for the center-east region of Cameroon was acquired in 1970, within the scope of a cooperative agreement between the government of 
Canada and that of the Federal Republic of Cameroon, under the auspices of the Canadian International Development Agency (ACDI). The flight lines were spaced $750 \mathrm{~m}$ and the flight direction was $\mathrm{N}$-S. The survey was carried out at a nominal terrain clearance of $235 \mathrm{~m}$ which was monitored by a radar altimeter with an accuracy of $+20 \mathrm{~m}$. The data set used in our study has been digitized with the aid of GIS techniques (MapInfo v7.5 software) and controlled with Microsoft Excel.

\subsection{Methodology}

\subsubsection{Total Magnetic Intensity Reduction to the Equator and Its Residual Anomaly}

After extraction, the aeromagnetic data survey was corrected and controlled on Excel. The anomaly of the total magnetic field (TMI) $\Delta B$ is the difference between the magnetic field extracted $B_{o b s}$ International Geomagnetic Reference Field (IGRF) $B_{\text {Ref }}$ to each station at the date February 15, 1970. This magnetic anomaly is given by:

$$
\triangle B=B_{O B S}-B_{R e f}
$$

The TMI map was reduced to the equator to ameliorate problems that are associated with low-latitude magnetic data [26]. RTE is complementary filter to Reduction-to-Pole (RTP) procedure. It transforms anomaly of non-zero inclination into an anomaly that would be observed on the same body with zero inclination. The RTE can be expressed as:

$$
R T E=\sin I+i \cos I \sin (D-\theta)^{2}
$$

where $I$ is the geomagnetic inclination, $D$ is the geomagnetic declination, $\sin I$ is the amplitude component, and $i \cos I \sin (D-\theta)^{2}$ is the phase component.

The software Geosoft of Oasis Montaj v.6.4 using the convolution of Fourier transformation made it possible to obtain the map of TMI reduced to the equator and other relevant maps. To realize this map, we computed Inclination (I) and of Declination (D) values. These values are: $I=-16.38$ and $D=-6$ respectively. The residual anomaly is calculated in each point of the regular grid by taking the difference between the anomaly of TMI RTE and Upward Continue to TMI RTE at $2 \mathrm{~km}$.

\subsubsection{Tilt Angle Approach}

Also known as Variation of inclination, the tilt angle is a transformation which includes the first vertical derivative and the module of the first horizontal derivative of the anomaly of residual TMI reduced to the equator. The advantage of the tilt angle is that, compared with the other methods, it does not require the knowledge of parameters such as (density, magnetic susceptibility, structural index etc...). The other advantages of this transformation of the tilt angle are that, by computing an angle, all the forms are represented in a similar way; such that the anomaly either has minimum or maximum amplitude and that it also allows mapping the features with high resolution. Indeed, the arc-tangent function has 
as effect, to distribute the signal calculated between $-90^{\circ}$ and $+90^{\circ}$. The tilt angle applied to the anomaly of the magnetic field reduced to the equator permits to estimate the depth of the upper end of the sources. According to [27] [28] [29] it is given by:

$$
\theta=\tan ^{-1}\left(\frac{\partial M / \partial z}{\partial M / \partial h}\right)
$$

where $\frac{\partial M}{\partial h}=\sqrt{\left(\frac{\partial M}{\partial x}\right)^{2}+\left(\frac{\partial M}{\partial y}\right)^{2}}$. Putting $H=\frac{\partial M}{\partial z}$ and $Z_{c}=\frac{\partial M}{\partial h}$, we deduce $\theta=\tan ^{-1}\left(\frac{H}{Z_{c}}\right)$. Thus $\theta=0^{\circ}$ for $H=0$ and $\theta= \pm \frac{\pi}{4}$ for $H= \pm Z_{C}$

In other words, the estimated depth of the upper end of the source is obtained by measuring the perpendicular distance between contours $\theta=0 \mathrm{rad}$ and $\theta= \pm \frac{\pi}{4} \mathrm{rad}$ to the feature. The map of tilt angle is obtained by using the software Geosolft of Oasis Montaj v.6.4. This transformed map presents a correlation (or analogy) with the geological structure of the basement in our study area with a description of the zones of contact of the geological formations.

\subsubsection{Euler Deconvolution Approach}

Euler deconvolution [30] is a method of estimating the depth of subsurface magnetic anomalies and can be applied to any homogeneous field of magnetic data [31]. In Euler's method, the structural index must be assumed as prior information because the quality of the depth estimation depends mainly on the choice of the proper structural index, which is a function of the geometry of the causative bodies and characterizes the rate of the variation of the anomaly intensity with a distance. [30] [32] showed that the optimum structural index usually yields the tightest clustering of the solutions. The depth estimates from magnetic data are more accurate with the equator-reduced magnetic field. The estimated Euler sources for the single-points are based on computing Euler's homogeneity Equation (4) and result in clusters used to constrain the overall geometry of the model. The 3D form of Euler's equation can be defined [33] as:

$$
\begin{aligned}
& \left(x-x_{o}\right) \frac{\partial F}{\partial x}+\left(y-y_{o}\right) \frac{\partial F}{\partial y}+\left(z-z_{o}\right) \frac{\partial F}{\partial z} \\
& =N(B-F)
\end{aligned}
$$

where $B$ is the regional value of the total magnetic field and $\left(x_{o}, y_{o}, z_{o}\right)$ is the position of the magnetic source, which produces the total magnetic field $F$ measured at $(x, y, z) . N$ is the Structural Index on how characterize the source.

Therefore, we have assigned a value of 1.0 as a structural index to locate the possible magnetic contacts because it is particularly good at delineating the subsurface contacts. We used an overlapping moving window of $10 \mathrm{~km}$ by $10 \mathrm{~km}$, a tolerance of $20 \%$ and a proportioned symbol base of 235 . 


\section{Results}

\subsection{Anomaly of Total Magnetic Intensity in the Studied Area}

The anomaly of the total magnetic field (TMI) is presented as 2D and 3D maps in Figure 2(a), Figure 2(b), respectively. Figure 2, the map shows the anomalies of TMI vary from $-214.7 \mathrm{nT}$ to $160 \mathrm{nT}$ and are distributed in a bipolar way on the study area. The correlation between the TMI anomalies map and geological
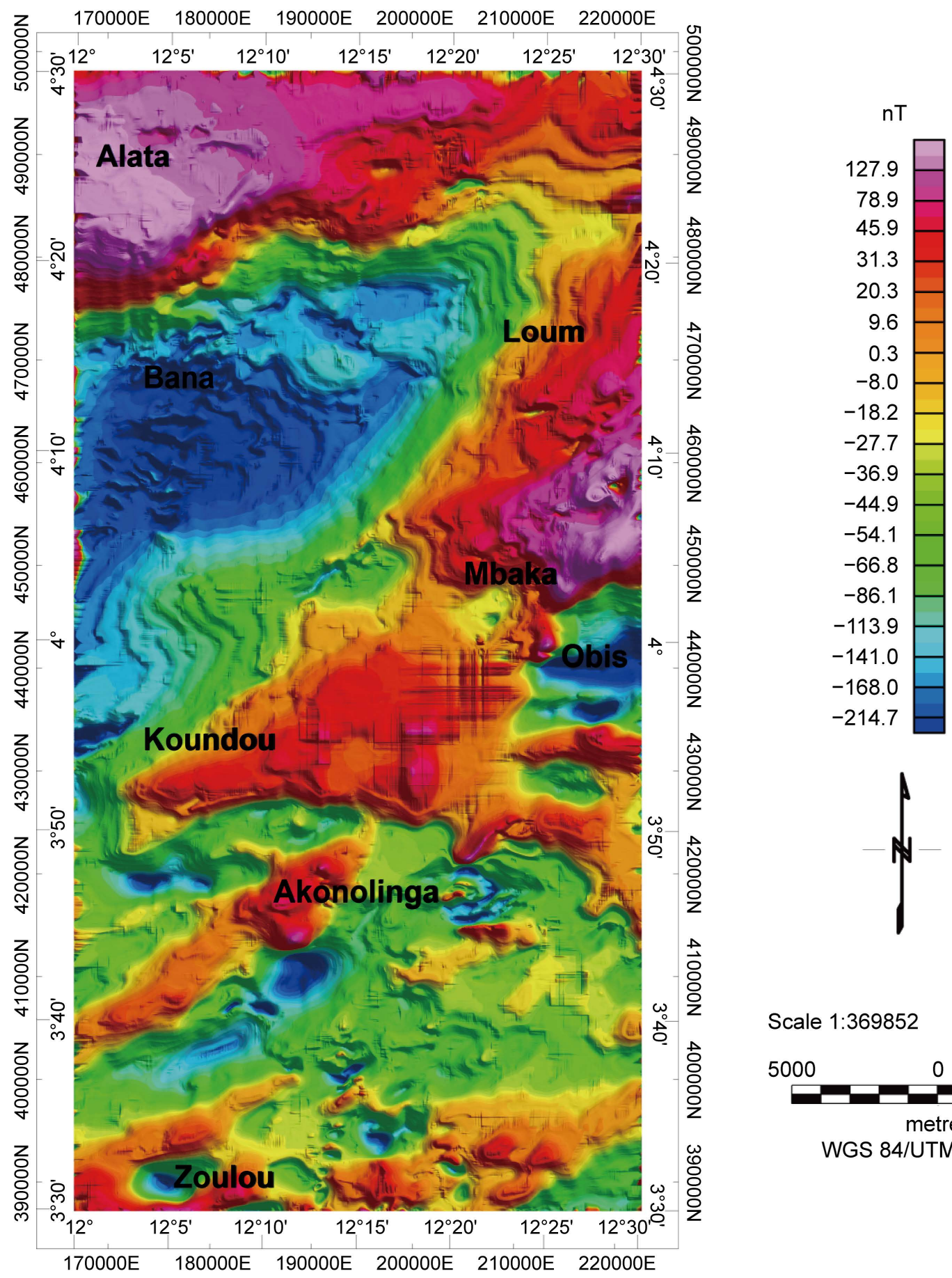

Scale 1:369852

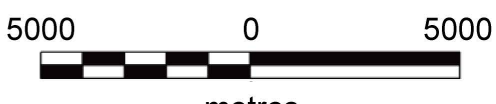

metres

WGS 84/UTM zone $32 \mathrm{~N}$

(a) 


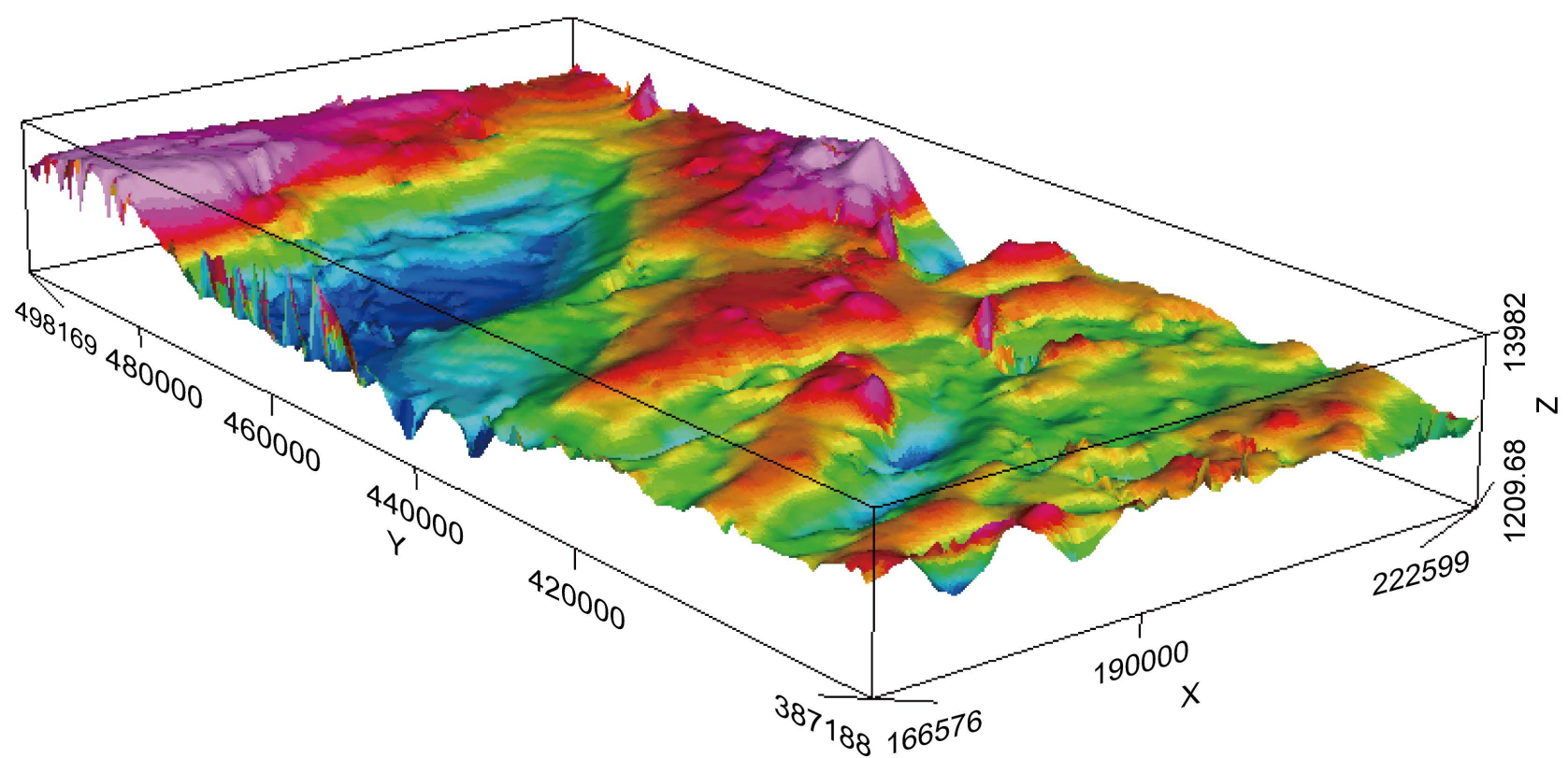

(b)

Figure 2. (a) Anomaly map of total magnetic intensity of the study area. (b) Three dimension anomaly of total magnetic intensity map of the study area.

contacts is weak. The only similarities are the zones of major faults (tectonic lines). It is noted that the positive anomalies are limited to the north by a weak gradient (quasi-horizontal gradient) translating the intensity of overlap of the geological formations and to the south by a high gradient (quasi-vertical gradient) translating a fracture or a normal fault. Also, we observe breaks at certain places in the strongly magnetic formations. These observations highlight the event of subduction of the CC under the Pan-African. At the Loum-Koundou region, a positive anomaly with a value reaching $160 \mathrm{nT}$ and a big wavelength of $66 \mathrm{~km}$ was observed. The Bana-Alata region is formed by a bipolar anomaly: a negative pole in Bana with a long wavelength of $44.4 \mathrm{~km}$ and negative amplitude of $-214.7 \mathrm{nT}$, and a positive pole in Alaka with a high amplitude $+160 \mathrm{nT}$ and wavelength $54.6 \mathrm{~km}$. In the Zoulou-Akonolinga region, heterogeneous anomalies are observed. Geologically, it would be due to the Schists of the group of Akonolinga, the Series of Mbalmayo-Benbis and the Series of Ayos associated with a conglomeration of quartzites. This explains the fact that this part is geologically covered by the mica-schist and the mica-quartzite. It could also have been created by the accumulation of minerals at the time of the events of intense activity. In the region, a diagonal prolongation on the anomalies of the TMI map of a contrast of susceptibilities is observed, highlighting a strongly magnetic zone. From a geological viewpoint, this zone marks a hiding of the schists which have a property of strong magnetization. In the Zoulou-Akonolinga region, we observe the magnetized diagonal prolongation which would be due to compound gneiss and the gneiss of the basic complex of the Nanga-Eboko series. Figure 2(b) show the spacial repartition of TMI anomalies. 


\subsection{Anomaly Total Magnetic Intensity Map Reduced to Equator}

The map of Figure 3 is the TMI-RTE, which also shows the great anomalies of minimal amplitude $-200 \mathrm{nT}$ and maximum amplitude $+110 \mathrm{nT}$, with long wavelengths. Generally, the anomalies preserve their forms compared to the TMI. This matches with the superposition of the greater part of the anomalies observed on the TMI of the geological sources hidden under the cover.
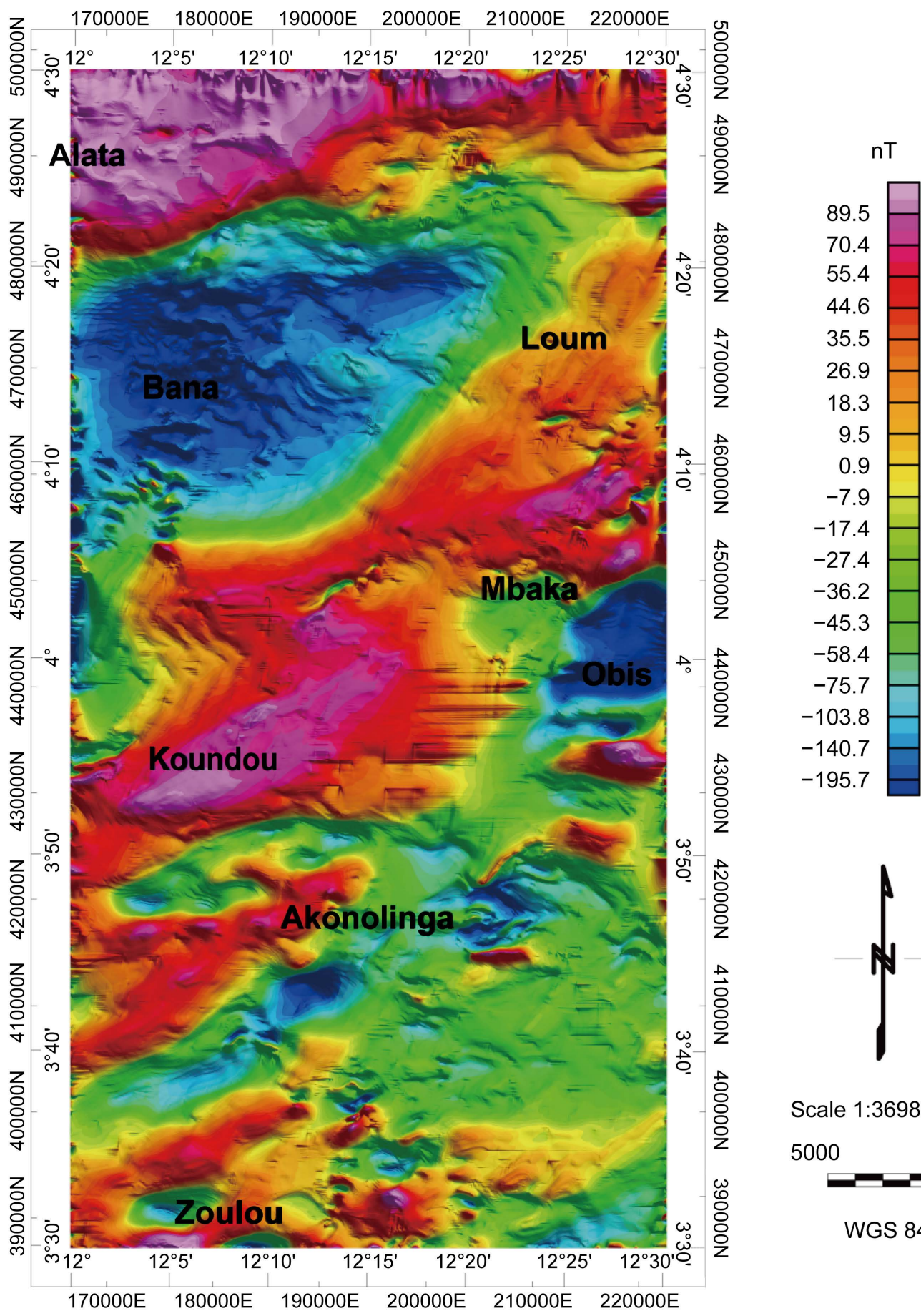

Figure 3. Total magnetic intensity anomaly map reduced to equator of the study area. 
We noted that the positive and the negative anomalies are limited to the north by a quasi-horizontal gradient and to the south by a quasi-vertical gradient. Also, we observe breaks at certain places in the strongly magnetic formations. These breakings would correspond to crustal features associated with zones with strong contrast. Also the extension of the anomalies shows magnetic peaks. This observation made evident the event of subduction of the CC under the PanAfrican.

The positive anomalies of the Koudou-Loum area persist, generally, but with a light displacement towards the south. These positive anomalies show the response of the strongly magnetized base. They thus indicate the formations of the schists of the Mbalmayo-Bengbis series and the Ayos series and of the schistquartzose group of Akonolinga, then further, the mica-schists of the basic complex of the series of Nanga-Eboko and the basic complex of the garnetiferous series. These schists are abundant in this zone, which leads us to suppose that they originate from the various intrusions noticed in this zone. From a mineralogical standpoint, according to the geological studies, they contain the chlorite-schists, the quartzites with two micas, the dominant quartzites, the micaschists with two micas and the quartzites, and the muscovites. Also, the negative anomalies in area indicate compound gneisses and the ectinites basic complex of the Nanga-Eboko series and of the Ayna series.

The positive anomalies of NE-SW direction tend to decrease in amplitude and wavelength to the NE (Loum) causing those to the SW (Koundou) to increase in these aspects. The strong circular anomalies in the zone translate the presence of accumulation of minerals of strong susceptibilities in the major faults. This is due to the presence on the one hand of diamagnetic minerals such as quartz and on the other, ferromagnetic minerals of strong residual magnetization such as the ectinites of the gneiss with biotites and compound gneisses with biotites in the basic complex of the Nanga-Eboko series, the Ayna series and the garnetiferous series, then the rocks of the magnesian series in the metamorphic complex of the South.

\subsection{Total Magnetic Intensity Residual of Study Area}

Figure 4 shows the map of residual anomaly. The values of the anomalies vary from $-68 \mathrm{nT}$ to $+48 \mathrm{nT}$ is a reduction of $112 \mathrm{nT}$ compared to the total field. This difference is a pointer to the fact that on the anomaly map of TMI, the effects of the surface structures are masked by those of the underlying structures. The high magnetic anomalies of Alata, Loum and Koundou have disappeared.

The anomalies are refined and point to the local maxima with NE-SW direction as previously noted on the maps of TMI and its transforms. This orientation of positive anomalies makes it possible to identify the directions of major structures and to locate them. The already mentioned magnetic peaks dissociate into several parts and breakings are observed. These magnetics peaks could be due to intrusions. 


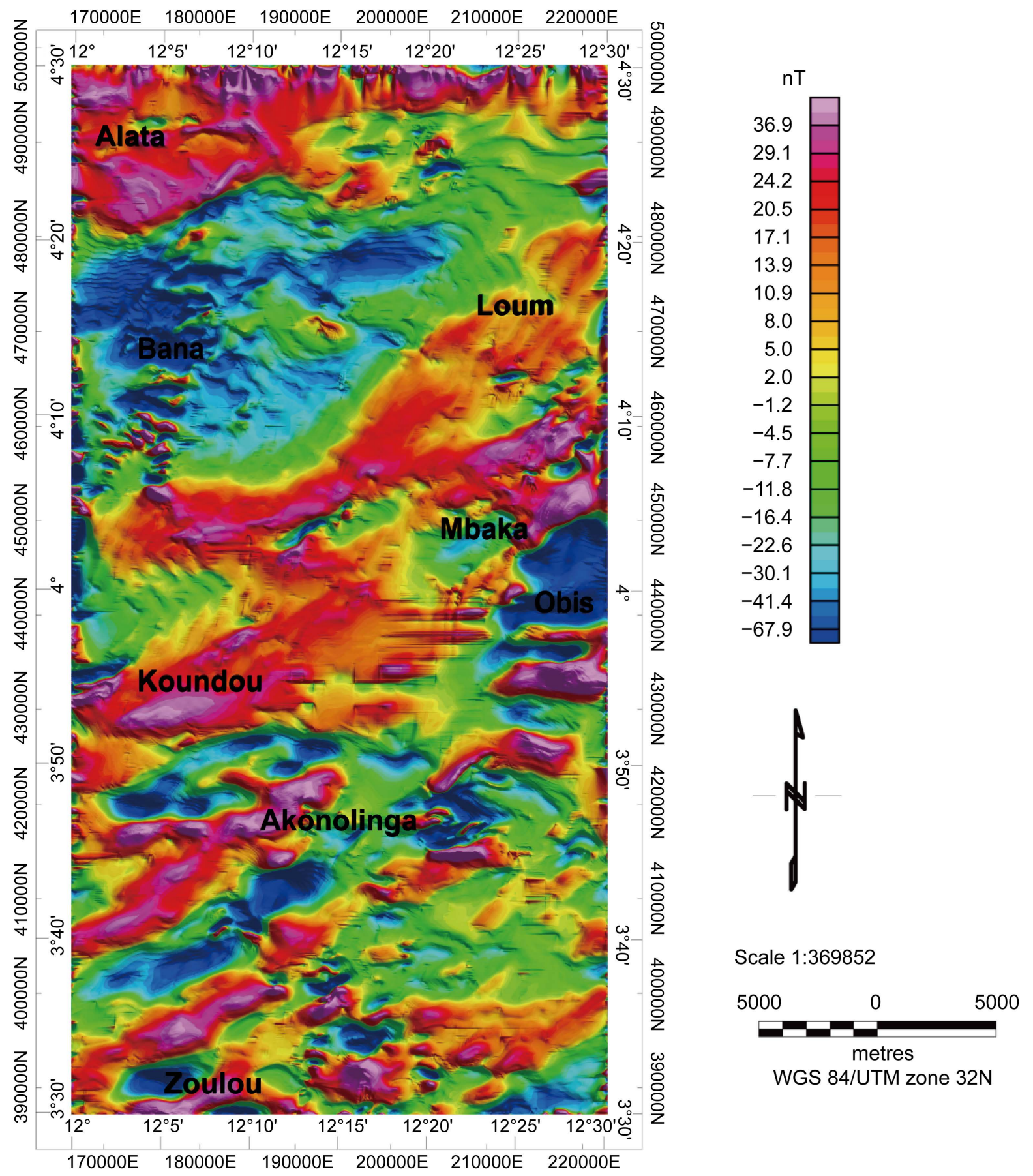

Figure 4. Anomaly total magnetic intensity residual map of the study area.

We notice the intrusion of the quartz mineral and the pegmatite and quartz in the mica-schist of the study area (around Alata). Also, we have the intrusion of the chlorite-schist, the quartzo-schists, the schists, the garnatiferous, micaschists, the quartz with two micas, and the gneiss in south part of the study area.

To the south of the positive anomalies, the passage from the positive anomaly to the negative anomaly is quasi-vertical and represents the vertical contact from the covers right to the base. To the north of the positive anomalies, the passage 
from the positive anomaly to the negative anomaly is quasi-horizontal and marks the overlapping of the geological formations. We observed that magnetic directions are linked with the tectonic lines. We noted a curvilinear contact to the south of the positive anomalies between the parallels $3^{\circ} 47^{\prime} \mathrm{N}$ and $3^{\circ} 75^{\prime} \mathrm{N}$. This contact (black line in Figure 4) is the vertical contact starting from the covers to the base. We assimilated it to the prolongation of the limit of the CC and the Pan-African as underlined by [7] [10] [11] along the parallel $4^{\circ} \mathrm{N}$.

\subsection{Variation of Inclination Angles (Tilt Angles)}

Figure 5(a) shows the Tilt angle of the residual TMI. The structural features are
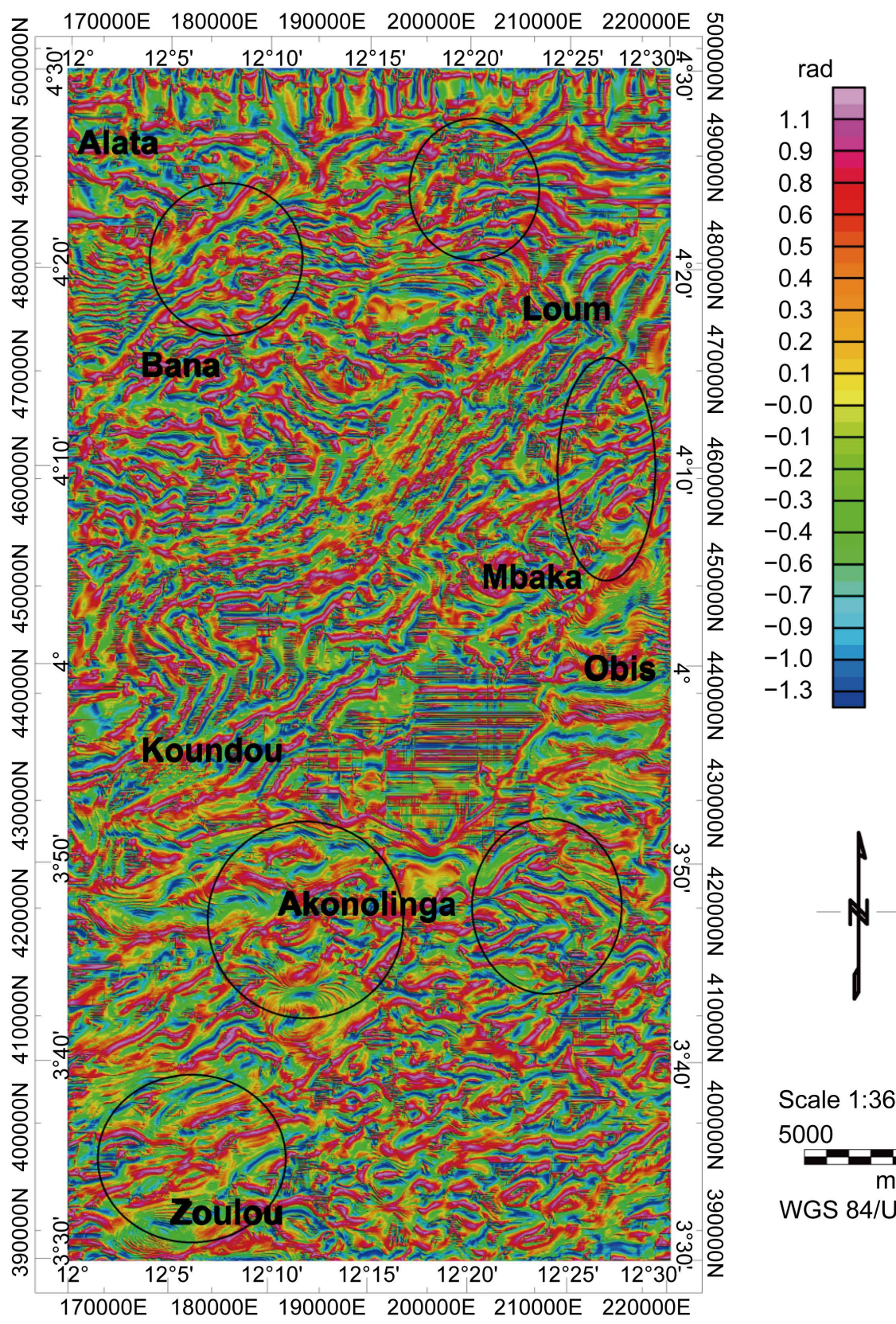

Scale 1:369852

5000

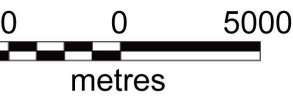

WGS 84/UTM zone 32N

(a) 

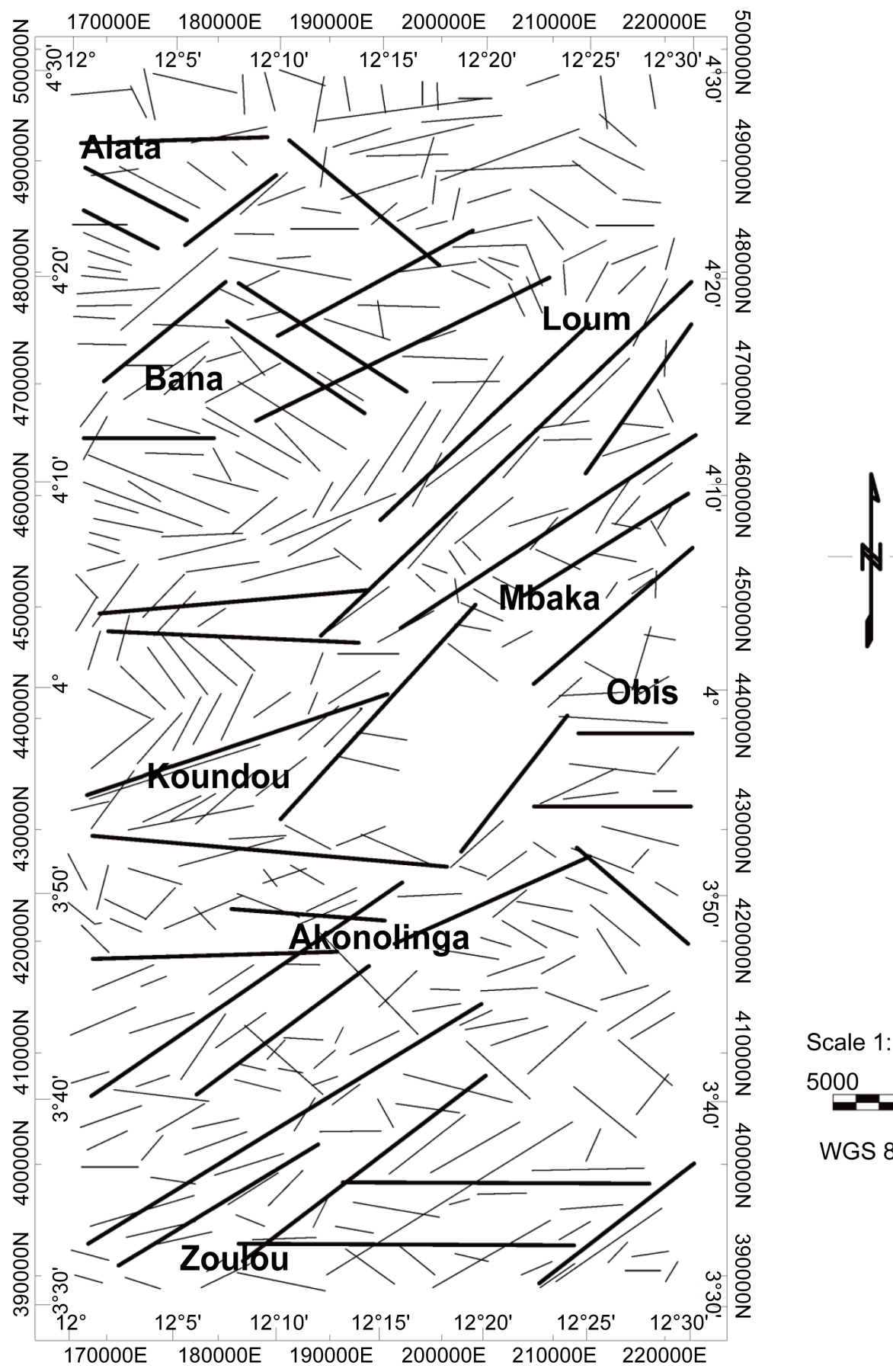

Scale 1:369852

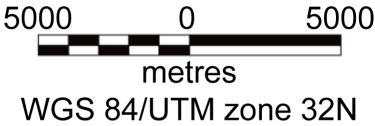

(b)

Figure 5. (a) Variation of magnetic inclination. (b) Lineaments of Variation of magnetic inclination.

viewed with a very high resolution. All the signals computed are distributed between -90 and +90 , the amplitudes of the angles vary between $-1.3 \mathrm{rad}$ and +1.3 rad while the lengths also vary. This map of variation of the angle of inclination shows several features of the subsurface which were nonvisible on the geological map. The interpretation of the aeromagnetic data shows several aeromagnetic features in our zone of study. The preceding maps allowed us to observe break- 
ings. At zones of breaking observed earlier, we noted a swirl of features, thus materializing a strong potential of the chlorite-schists and strongly laminated quartzite-schists, folded and undulated in the mica-schists in the southern part of the study zone correlating the geology of [15] reviewed by [1]-[19].

37 major features and 523 minor features are obtained in this zone, making 560 features. The principal features resulting on this map (solid lines appearing in Figure 5(b)) are correlated with the direction of magnetic anomalies from the map of residual TMI in Figure 4. These principal features have lengths varying from $10.8 \mathrm{~km}$ to $47.7 \mathrm{~km}$, the depths going from $0.3 \mathrm{~km}$ to $2.6 \mathrm{~km}$. The characteristics (directions, lengths and depths) of the principal features are grouped in Table 1. The minor features (foliations) show an affected base by tectonics which characterizes the transition between the zone from the Congo Craton and the belt folds from the Pan-African. In the north, foliations have the quasi-parallel texture forming folds with an NE direction and slopes varying from $30^{\circ}$ to $60^{\circ}$ with a sinistral asymmetry. In the south, foliations have anarchical directions, sometimes indicating boudinages structures, sometimes of the folded structures. The Rosacea diagram of the major lineament orientations (Figure 6(a)), and the rosacea diagram of the minor lineament orientations (Figure $6(\mathrm{~b})$ ) show the

Table 1. Direction of major features, their lengths and their depths resulting from Tilt angle (depth 1), resulting from the Euler's solution of (depth 2).

\begin{tabular}{|c|c|c|c|c|c|c|c|c|c|}
\hline $\mathrm{N}^{\circ}$ & Direction $\left({ }^{\circ}\right)$ & Length $(\mathrm{km})$ & Depth $1(\mathrm{~km})$ & Depth $2(\mathrm{~km})$ & $\mathrm{N}^{\circ}$ & Direction $\left({ }^{\circ}\right)$ & Length $(\mathrm{km})$ & Depth1 (km) & Depth $2(\mathrm{~km})$ \\
\hline 1 & N87E & 20.0 & 1.4 & $0.2-0.5$ & 20 & N94E & 31.9 & 2.5 & $0.2-0.8$ \\
\hline 2 & N51E & 11.5 & 1.6 & $0.2-0.8$ & 21 & $\mathrm{~N} 42 \mathrm{E}$ & 17.7 & 2.4 & $0.2-0.6$ \\
\hline 3 & N119E & 13.6 & 0.5 & $0.2-0.5$ & 22 & N94E & 16.1 & 2.6 & $0.9-0.6$ \\
\hline 4 & N123E & 10.0 & 1.4 & $0.3-1.6$ & 23 & N63E & 18.8 & 0.8 & $0.2-0.5$ \\
\hline 5 & N128E & 16.3 & 0.6 & $0.2-0.9$ & 24 & N133E & 13.1 & 1.2 & $0.2-1.1$ \\
\hline 6 & N57E & 20.2 & 1.1 & $0.2-0.5$ & 25 & N99E & 14.0 & 1.5 & $0.2-0.7$ \\
\hline 7 & N122E & 18.4 & 1.6 & $0.2-0.7$ & 26 & N55E & 35.9 & 1.8 & $0.2-1.6$ \\
\hline 8 & N64E & 28.9 & 1.6 & $0.2-1.6$ & 27 & N85E & 24.5 & 1.14 & $0.3-1.6$ \\
\hline 9 & $\mathrm{~N} 126 \mathrm{E}$ & 14.2 & 0.8 & $0.2-0.9$ & 28 & N53E & 19.2 & 1.7 & $0.2-1.6$ \\
\hline 10 & N96E & 13.4 & 0.7 & $0.2-0.8$ & 29 & N59E & 41.8 & 2.3 & $0.2-1.6$ \\
\hline 11 & $\mathrm{~N} 48 \mathrm{E}$ & 25.3 & 2.1 & $0.2-1.6$ & 30 & N58E & 20.9 & 2.6 & $0.4-1.6$ \\
\hline 12 & N47E & 47.7 & 2.5 & $0.2-1.6$ & 31 & N52E & 29.9 & 1.7 & $0.3-0.6$ \\
\hline 13 & $\mathrm{~N} 39 \mathrm{E}$ & 17.3 & 1.0 & $0.2-0.6$ & 32 & N93E & 27.4 & 1.5 & $0.2-0.7$ \\
\hline 14 & N85E & 24.6 & 1.8 & $0.2-1.6$ & 33 & N94E & 26.6 & 1.6 & $0.3-1.6$ \\
\hline 15 & N93E & 20.0 & 1.0 & $0.2-1.1$ & 34 & N53E & 17.5 & 1.9 & $0.9-1.6$ \\
\hline 16 & N54E & 30.9 & 1.1 & $0.5-1.6$ & 35 & N85E & 11.8 & 2.6 & $0.4-0.6$ \\
\hline 17 & N72E & 28.8 & 2.4 & $0.2-1.1$ & 36 & N50E & 14.0 & 0.6 & $0.4-0.9$ \\
\hline 18 & N44E & 27.3 & 1.1 & $0.2-1.1$ & 37 & N45E & 18.8 & 1.6 & $0.3-1.6$ \\
\hline 19 & N47E & 18.7 & 2.5 & $0.6-1.6$ & & & & & \\
\hline
\end{tabular}




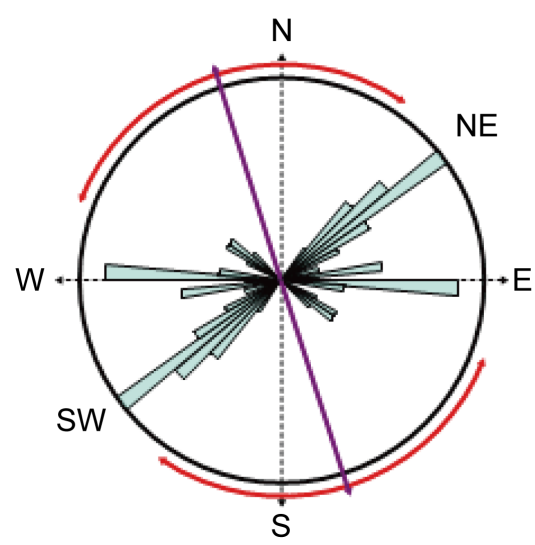

(a)

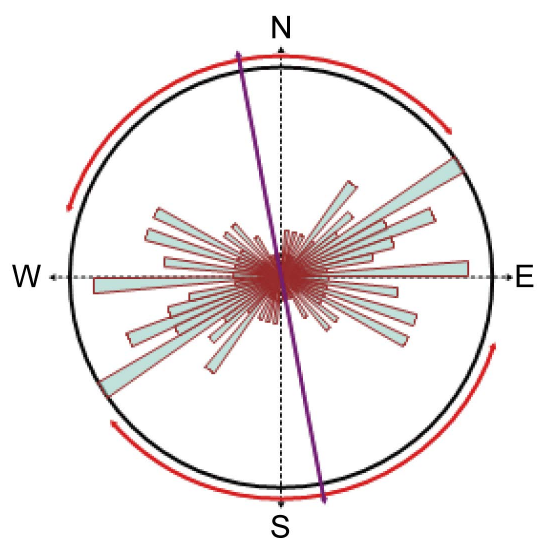

(b)

Figure 6. (a) Rosacea diagram of the major lineament orientations; (b) Rosacea diagram of the minor lineament orientations.

directions of lineaments. We thus we obtain four great directions of the structures: SW-NE, WSW-ENE, W-E and NW-SE. The principal direction is SW-NE. All directions are associates at those of tectonic lines.

\subsection{Euler Deconvolution}

\subsubsection{Euler Deconvolution of Residual Field}

The Euler's solutions enable the determination of the geometry of intruding bodies, generally in structures, and thence to correlate them with geological structures. The map of Figure 7 shows the results of the Euler Deconvolution method applied to the map of residual anomaly of the TMI.

On this map, we have the Euler's solution for structural indices $\mathrm{N}=1$, tolerance $\mathrm{T}=20 \%$ and Nyquist Window $\mathrm{W}=10 \mathrm{~km} \times 10 \mathrm{~km}$. The Euler's solutions have depths varying from $200 \mathrm{~m}$ to $3000 \mathrm{~m}$, including those of the bodies with their geometries. The structural interpretation of the map shows the various features affecting our study area. We distinguish the deep features and the limit of the intrusive bodies. On these maps, we observe four great directions of the structures which are: SW-NE, WSW-ENE, W-E and NW-SE. We also observe tectonic lines resulting from the geological map. At some points, the disposition of the Euler's solutions characterize the fracture between Bana and Loum, the seams in the East and the South-east of Alata, the prolongation of the CC limit and the Pan-African along Koundou-Loum with a depth estimated at $2.6 \mathrm{~m}$, the intrusions in the base of the schists of Mbalmayo-Bengbis and Ayos both in the south and in the north, and equally the gneiss of the basic complex around Bana.

As underlined by [34] such lineaments could be created by crustal faulting during the Pan-African orogeny and could correspond to deep-seated basement structures related to the inferred tectonic boundary separating the Craton and the mobile belt.

\subsubsection{Euler Deconvolution of Variation of the Inclination (Tilt Angle)}

The map of Figure 8 is that of the Euler's solution for the underlying deep 


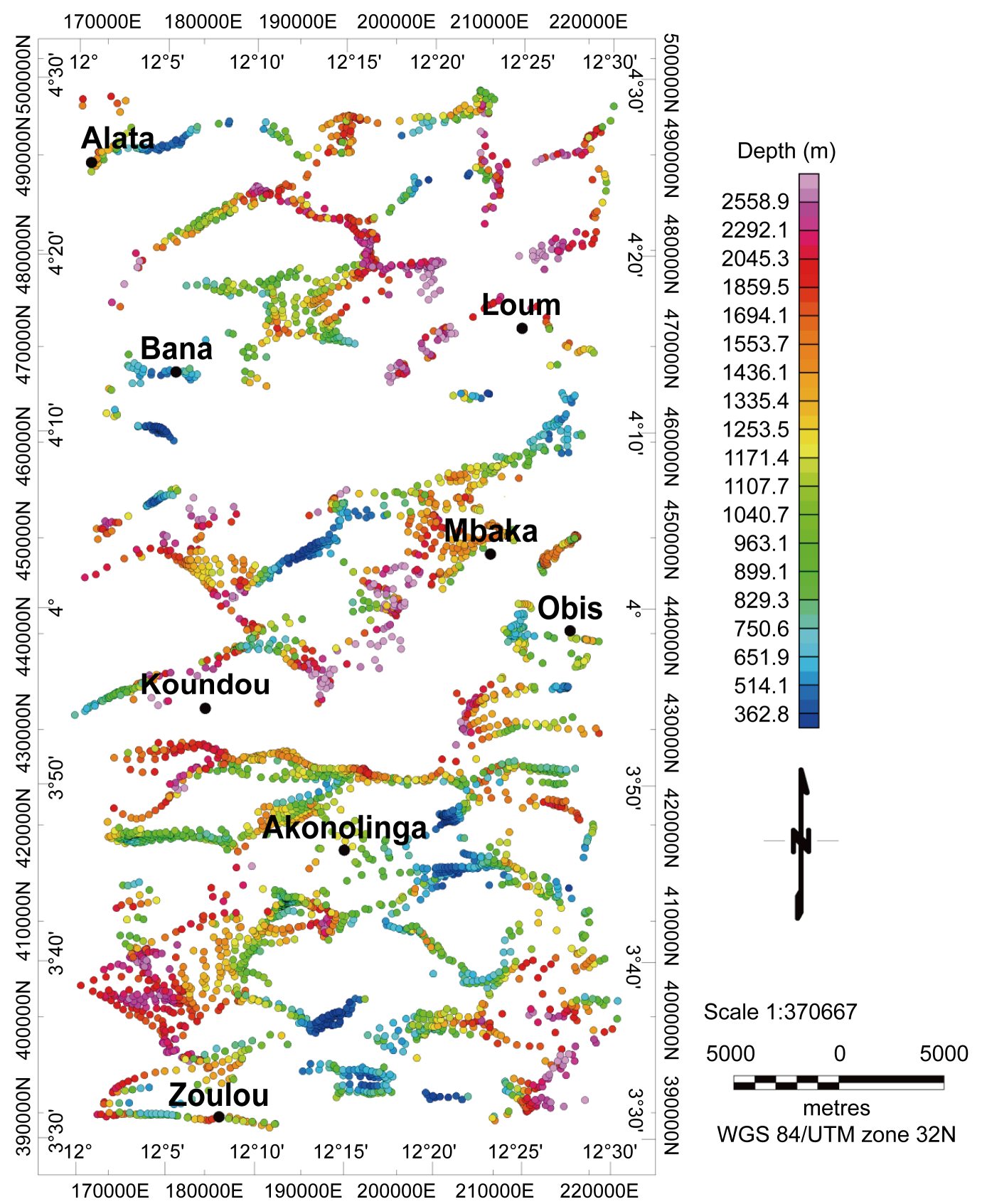

Figure 7. Euler's solution of TMI residual $\mathrm{N}=1, \mathrm{~T}=20 \%, \mathrm{~W}=10 \mathrm{~km} \times 10 \mathrm{~km}$.

structures having depths varying from $100 \mathrm{~m}$ to $3000 \mathrm{~m}$. It is used for the final interpretation of the geological contacts associated to the features noted previously. This map shows more details of the depth of the intruding geological structures in the base. The extent of the number of structures on the map highlights the intense tectonic activity that this area undergoes. This is the reason of the metamorphism of the cover, renovated by the internal stress at the time of the collision. We effectively observe the disposition of lineaments, the CC limit and the Pan-African. The variation of the depth of the structures in this map is proof of the fact that this area belongs to the mobile zone. The probable slope of 


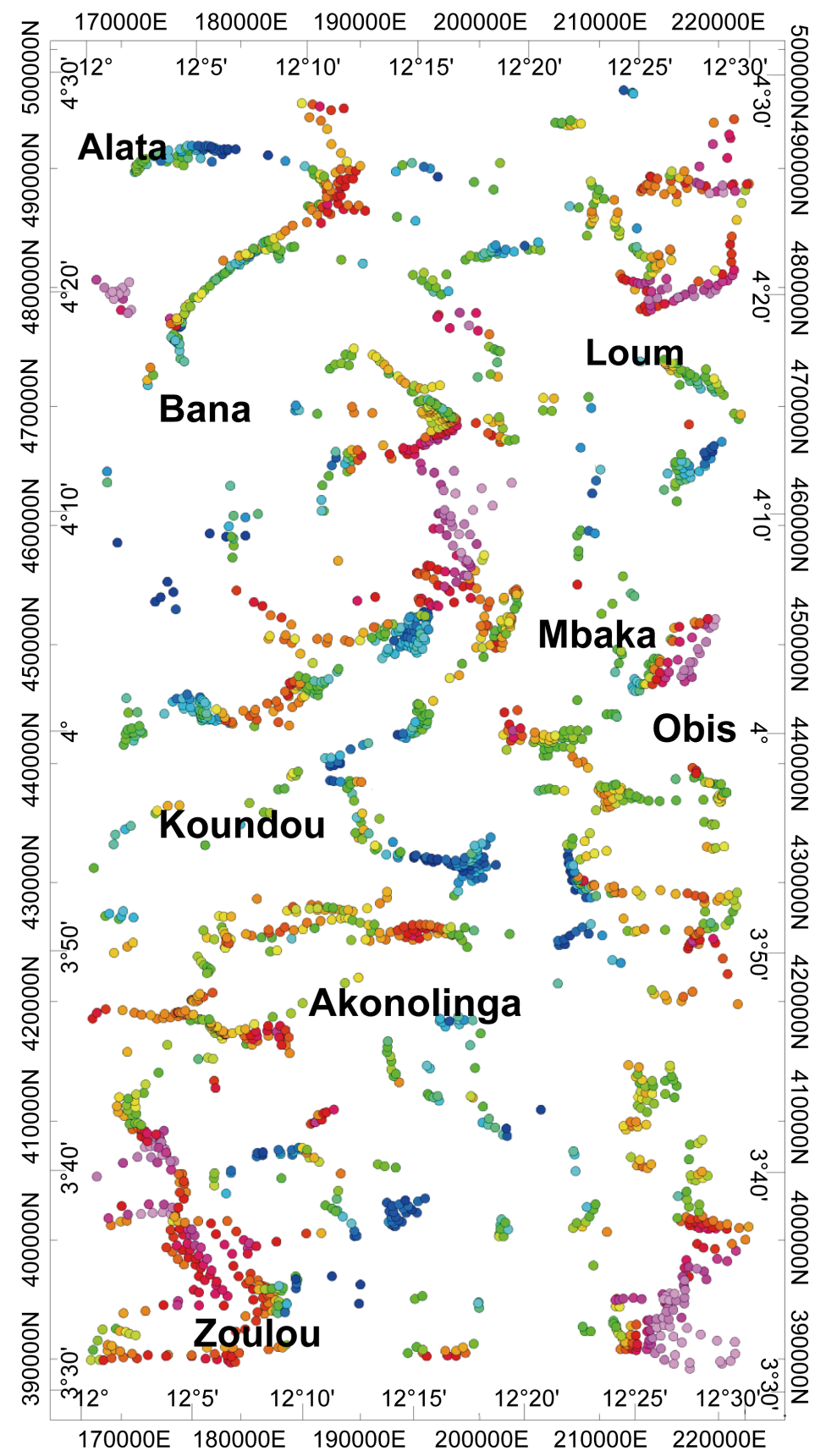

Depth $(\mathrm{m})$

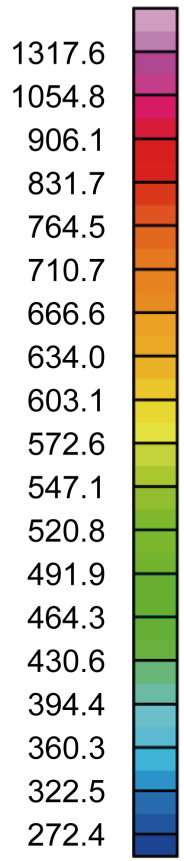

Scale 1:386207

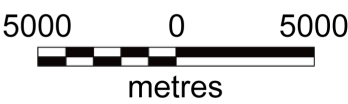

WGS 84/UTM zone $32 \mathrm{~N}$

Figure 8. Euler's solution of VIM N =1, T =20\%, W $=10 \mathrm{~km} \times 10 \mathrm{~km}$.

lineaments in the northern part of the region varies from $30^{\circ}$ to $60^{\circ} \mathrm{SE}$ while in the southern part it varies from $30^{\circ}$ to $60^{\circ} \mathrm{NW}$.

\subsubsection{Correlation of Tilt Angle Structures and Its Euler's Deconvolution Map}

The interpretation of the overlapping maps is based on the following criteria:

- If the features of the Variation of the Magnetic Inclination (VMI) and those of the Euler solution are almost parallel and do not merge, the VMI features represent the contacts while those of Euler's solutions indicate the sense and 
direction of their slopes for these contacts and the overlapping of the ores located in these features.

- If the features of the VMI and those of the Euler's solution are almost parallel and are merged, the VMI features represent the contacts while those of the Euler solution indicate the direction and sense for the vertical slopes of these contacts and the vertical gradients affecting the base.

The map of Figure 9 shows the superposition of the features resulting from the VMI and the Euler's solutions which are almost parallel and their slopes are similar to those obtained within the framework of the geological study.

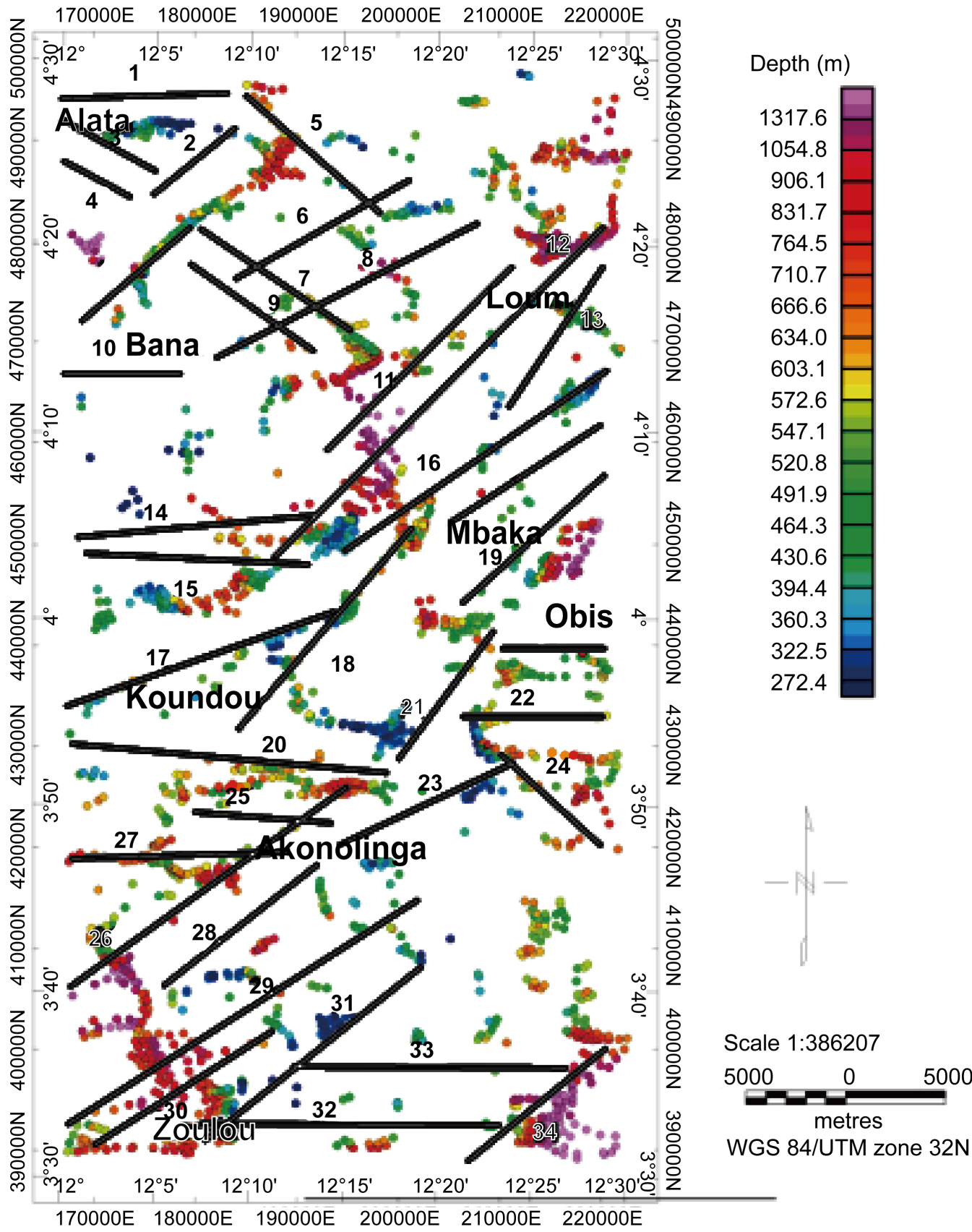

Figure 9. Superposition of the Euler's solution of VMI map and the structural VMI map. 
These slopes are sinistral in the north and dextral in the south. Agravimetric survey of underground structures based on a 2.5D modelling of Bouguer Gravity anomalies in the Mengueme-Ayos area shows evidence of a dextral wrench fault with average W-E strike and a steep dip of $61^{\circ}$ [11]. This is the reason why the magnetic method is the best for the study of structures. The slopes are similar to those observed previously.

\section{Discussion}

The anomalies of the TMI (Figure 2) obtained during the processing of our data have as global direction, SW-NE, corresponding to the structures related to the schistose intrusions. This confirms the results of the gravimetric study made by [6] [7].

We assembled the structural map of the VMI (Figure 5(a) \& Figure 5(b)) and the Euler's solution Deconvolution, and checked that the main structural direction is SW-NE. This structural direction had equally been obtained by [6] [7], in an audio-magnétotelluric study carried out by [12] and in an aeromagnetic study done by [10]. The structural map makes it possible to observe a network of faults in our study area and thus to show that the network of faults observed by [14] in the southern zone of our area is prolonged into our zone. The continuity of this prolongation eastwards of our zone is highlighted in the audio-magnétotelluric study done by [23].

We showed that on the southern frontages of the positive anomalies, the passage from the positive anomaly to the negative anomaly (Figures 2-4) is characterized by vertical geometries especially the gradient in the center-south of our zone between Akonolinga and Koundou down to the south of Obis. Geometrically, this structure describes the open synclinal transposed on vertical foliations: the major faults along the northern limit of the $\mathrm{CC}$ as [7] in a gravimetric study also obtained; on the northern fronts, the passage from the positive anomalies to the negative anomalies (Figures 2-4) is characterized by their geometries which are almost horizontal and this describes open anticline geometrical structures.

This curvilinear vertical contact (black line in Figure 4) in the south of the positive anomalies between the parallels $3^{\circ} 47^{\prime} \mathrm{N}$ and $3^{\circ} 75^{\prime} \mathrm{N}$ goes from the covers to the base and marks the boundary of the CC with the Pan-African of approximate depth $2.6 \mathrm{~km}$, according to the Euler's solution of the anomaly for residual TMI, $1.6 \mathrm{~km}$ according to Tilt Angle, and main direction SW-NE. Therefore, these indicate a geological deformation which occurred at the time of the intense the collision of the CC and the Pan-African belt [1] [2] [3] [4] [5] where there was a subduction of the solid CC body and the less solid Pan-African body [6] [7] [8].

The map of VMI (Figure 5(a)) shows that the contacts are not simple; we observe boudinages in the south and folds in the center on a hundred meters scale. These contacts are compatible with those of the map of TMI-RTE (Figure 3). They show a series of deformations with a principal SW-NE direction under 
conditions which are realized in extreme cases of the metamorphic state, which according to [17] have a rather recent deformation.

These conditions of deformation are underlined by the presence of the mica-schist in the South, of the schists in center-east and compound gneiss in the center-west of this area. From this study, we have therefore supposed 6 zones of major interest represented by circles on the VMI map (Figure 5(a)); three in the south and three in the north. It exhibits many more major features than the map of the variation of the inclination thus making it possible to see that in our study area, the major features go from the cover to the base.

The features show a base strongly affected by tectonics which characterizes the transition between the zone from the Congo Craton and the belt from folds for the Pan-African. This, together with the previous observations leads us to say that our zone of study belongs to the mobile zone of the Central Africa as in the gravimetric study made by [11].

\section{Conclusions}

The main results obtained in this study highlight new elements which allow the improvement of our knowledge on the geological structures of the study area. The tilt angle method is used to delineate geological contacts and structures and to estimate the depth and the length. Principal and secondary lineaments are determined with the main direction being SW-NE. We observe that there is a faulting system in our study area. We estimate the northern boundary of the CC and the southern boundary of the Pan-African starting from $3^{\circ} 47^{\prime} \mathrm{N}$ to $3^{\circ} 75^{\prime} \mathrm{N}$; its depth is estimated around $2.6 \mathrm{~km}$ for the deep part and $0.1 \mathrm{~km}$ for the shallow, the direction is WSW-ENE while the slope (NW) varies from $30^{\circ}$ to $60^{\circ}$. This study enables a better knowledge of the subsurface structure of this area.

This study has enabled us to show that the collision of the CC block and the Pan-African block included the features and led to a rejuvenation of the crust in this part. This renovation brought about intrusions of schistose, chlorite schistose, quartzite in the mica-schist and the intrusions of the gneiss-garnetiferous in compound gneiss. During these events of the synclinal and anticlinal geological deformations arose, followed by the installation of boudinage structures and folds; the pegmatite and quartz seams were also formed. Six mining zones of interest were thus identified, three in the south and three in the north. A geophysical exploration will enable us to specifically stress on these zones of interest.

\section{Acknowledgements}

The authors are grateful to the reviewers and the readership for their kind help in making the manuscript clearer, more correct and mature for publication.

\section{References}

[1] Toteu, S.F., Yongue-Fouateu, R., Penaye, J., Tchakounte, J., Seme-Mouangue, A.C., Van-Schmus, R.W., Deloule, E. and Stendal, H. (2006) U-Pb Dating of Plutonic 
Rocks Involved in the Nappe Tectonic in Southern Cameroon: Consequence for the Pan-African Orogenic Evolution of the Central African Fold Belt. Journal of African Earth Sciences, 44, 479-493.

[2] Abdelsalam, M.G., liégeois, J.P. and Stern, R.J. (2002) The Saharan Metacraton. Journal of African Earth Sciences, 34, 119-136.

[3] Castaing, C., feybesse, J.L., Thieblemont, D., Triboulet, C. and Chèvremont, P. (1994) Paleogeographical Reconstructions of the Pan-African/Brasilianoorogen: Closure of an Oceanic Domain or Intracontinental Convergence between Major Blocks? Precambrian Research, 67, 327-344.

[4] Nzenti, J.P., Barbey, P., Macaudiere, J. and Soba, D. (1988) Origin and Evolution of the Precambrian High Grade Yaoundé Gneiss (Cameroon). Precambrian Research, 38, 91-109.

[5] Nzenti, J.P., Barbey, P., Jegouzo, P. and Moreau, C. (1984) Un nouvel exemple de ceinture granulitique dans une chaîne protérozoïque de collision: Les migmatites de Yaoundé au Cameroun. Comptes Rendu de l'Académie des Sciences de Paris, 299, 1197-1199.

[6] Shandini, N.Y., Tadjou, J.M., Tabod, C.T. and Fairhead, J.D. (2010) Gravity Data Interpretation in the Northern Edge of the Congo Craton, South-Cameroon. Anuário do Instituto de Geociências, 33, 73-82.

[7] Tadjou, J.M., Nouayou, R., Kamguia, J., Kande, H.L. and Manguelle-Dicoum, E. (2009) Gravity Analysis of the Boundary between the Congo Craton and the Pan-African Belt of Cameroon. Australian Journal of Earth Sciences, 102, 71-79.

[8] Manguelle-Dicoum, E., Bokosah, A.S. and Kwende-Mbanwi, T.E. (1992) Geophysical Evidence for a Major Precambrian Schist-Granite Boundary in Southern Cameroon. Tectonophysics, 205, 437-446.

[9] Nédélec, A., Macaudière, J., Nzenti, J. and Barbey, P. (1986) Évolution structurale et métamorphique des scihtes de Mbalmayo (Cameroun) Implications pour la structure de la zone mo-bile panafricaine d'Afrique centrale au contact du craton du Congo. Comptes Rendus de I Académie des Sciences, 303, 75-80.

[10] Ndougsa-Mbarga, T., Yufenyiu Layu, D., Quentin Yene-Atangana, J. and Tabod, C. (2014) Delineation of the Northern Limit of the Congo Craton Based on Spectral Analysis and 2.5 D Modeling of Aeromagnetic Data in the Akonolinga-Mbama Area, Cameroon. Geofísica internacional, 53, 5-16.

[11] Ndougsa-Mbarga, T., Manguelle-Dicoum, E., Tabod, C.T. and Mbom-Abane, S. (2003) Modélisation d'anomalies gravimétriques dans la région de MenguemeAkonolinga (Cameroun). Science, Technology and Development, 10, 64-74.

[12] Ndougsa-Mbarga, T., Meying, A., Bisso, D., Sharma, K.K., Layu, D.Y. and ManguelleDicoum, E. (2011) Audiomagnetotelluric (AMT) Soundings Based on the Bostick Approach and Evidence of Tectonic Features along the Northern Edge of the Congo Craton, in the Messamena/Abong-Mbang. The Journal of Indian Geophysical Union, 15, 145-159.

[13] Gazel, J. and Guiraudie, C. (1965) Notice Explicative sur la Région Abong-Mbang Ouest de la Carte Géologique de Reconnaissance à l'échelle du 1/500.000. Direction des Mines et Géologie, Yaoundé, 29 p.

[14] Feumoe, A.N.S., Ndougsa-Mbarga, T., Manguelle-Dicoum, E. and Derek Fairhead, J. (2012) Delineation of Tectonic Lineaments Using Aeromagnetic Data for the South-East Cameroon Area. Geofizika, 29.

[15] Gazel, J. (1955) Notice Explicative sur la Région Batouri-Ouest Ouest de la Carte Géologique de Reconnaissance à l'échelle du 1/500.000. Direction des Mines et 
Géologie, Yaoundé, 23 p.

[16] Paterson, Grant, Watson Ltd. (1976) Etudes aeromagnetiques sur certaines Régions de la République Unie du Cameroun. Rapport d'interprétation. ACDI, Toronto, 190 p.

[17] Olinga, J.B., Mpesse, J.E., Minyem, D., Ngako, V., Ndougsa-Mbarga, T. and Ekodeck, G.E.(2010) The Awaé-Ayos Strike-Slip Shear Zones (Southern-Cameroon) Geometry, Kinematics and Significance in the Late Pan African Tectonics. Neues Jahrbuch für Geologie und Paläontologie-Abhandlungen, 257, 1-11. https://doi.org/10.1127/0077-7749/2010/0042

[18] Bessoles, B. and Lasserre, M. (1977) Le complxe de base du Cameroun. Bulletin de la Société Géologique de France, 19, 1085-1092. https://doi.org/10.2113/gssgfbull.S7-XIX.5.1085

[19] Toteu, S.F., Penaye, J. and Poudjom Djomani, Y. (2004) Geodynamic Evolution of the Pan-African Belt in Central Africa with Special Reference to Cameroon. Canadian Journal of Earth Sciences, 41, 73-85. https://doi.org/10.1139/e03-079

[20] Djouka, F.M.L., Schüssler, U. and Tchouankoue, J.P. (2004) Geochemistry and Petrogenesis of Neoproterozoicgranitoids within the Central African Fold Belt in the Bafoussam Area, Western Cameroon (Central Africa). University of Wuerzburg, 4 p.

[21] Vicat, J.P. (1998) Esquisse géologique du Cameroun. Collection GEOCAM, Presses Universitaire Yaoundé, 3-11.

[22] Noutchogwe, C., Tabod, C. and Manguelle-Dicoum, E. (2006) A Gravity Study of the Crust beneath the Adamawa Fault Zone, West Central Africa. Journal of Geophysics and Engineering, 3, 82-89. https://doi.org/10.1088/1742-2132/3/1/009

[23] Meying, A., Ndougsa-Mbarga, T. and Manguelle-Dicoum, E. (2009) Evidence of Fractures from the Image of the Subsurface in the Akonolinga-Ayos Area (Cameroon) by Combining the Classical and the Bostick Approaches in the Interpretation of Audio-Magnetotelluric Data. Journal of Geology and Mining Research, 1, 159-171.

[24] Mvondo, H., Owona, S., Mvondo-Ondoa, J. and Essono, J. (2007) Tectonic Evolution of the Yaoundé Segment of the Neoproterozoic Central African Orogenic Belt in Southern Cameroon. Canadian Journal of Earth Sciences, 44, 433-444. https://doi.org/10.1139/e06-107

[25] Mbom-Abane, S. (1997) Investigations géophysiques en bordure du craton du Congo (régiond'AbongMbang/Akonolinga, Cameroun) et implications structurales. $\mathrm{PhD}$ Thesis, Université de Yaoundé I, $180 \mathrm{p}$.

[26] Grauch, V.J.S., Bauer, P.W. and Kelson, K.I. (2004) Preliminary Interpretation of High-Resolution Aeromagnetic Data Collected near Taos, New Mexico. New Mexico Geological Society, 55 th Field Conference, Guidebook, 244-256.

[27] Salem, A., William, S., Fairhead, D., Ravat, D. and Smith, R. (2007) Tilt-Depth Method: A Simple Depth Estimation Method Using First-Order Magnetic Derivatives. The Leading Edge, 150, 2-5. https://doi.org/10.1190/1.2821934

[28] Verduzco, B., Fairhead, J.D., Green, C.M. and MacKenzie, C. (2004) New Insights into Magnetic Derivatives for Structural Mapping. The Leading Edge, 23, 116-119. https://doi.org/10.1190/1.1651454

[29] Miller, H.G. Singh, V. (1994) Potential Field Tilt a New Concept for Location of Potential Field Sources. Journal of Applied Geophysics, 32, 213-217.

[30] Reid, A.B., Allsop, J.M., Granser, H., Millett, A.J. and Somerton, I.W. (1990) Magnetic Interpretation in Three Dimensions Using Euler Deconvolution. Geophysics, 55, 80-90. https://doi.org/10.1190/1.1442774 
[31] Durrheim, R.J. and Cooper, R.J. (1998) EULDEP: A Program for the Euler Deconvolution of Magnetic and Gravity Data. Computer and Geosciences, 24, 545-550.

[32] Thompson, D.T. (1982) EUIDPH: A New Technique for Making Computer-Assisted Depth Estimates from Magnetic Data. Geophysics, 47, 31-37. https://doi.org/10.1190/1.1441278

[33] Reid, A.B. and Thurston, J.B. (2014) The Structural Index in Gravity and Magnetic Interpretation: Errors, Uses, and Abuses. Geophysics, 79, J61-J66. https://doi.org/10.1190/geo2013-0235.1

[34] Basseka, C.A., Shandimi, Y. and Tadjou, J.M. (2011) Subsurface Structural Mapping Using Gravity Data of the Northern Edge of the Congo Craton South Cameroon. Geofizika, 28, 229-245.

Submit or recommend next manuscript to SCIRP and we will provide best service for you:

Accepting pre-submission inquiries through Email, Facebook, LinkedIn, Twitter, etc. A wide selection of journals (inclusive of 9 subjects, more than 200 journals)

Providing 24-hour high-quality service

User-friendly online submission system

Fair and swift peer-review system

Efficient typesetting and proofreading procedure

Display of the result of downloads and visits, as well as the number of cited articles

Maximum dissemination of your research work

Submit your manuscript at: http://papersubmission.scirp.org/

Or contact ijg@scirp.org 